\title{
PERSONAGENS DA REDE: INDIVÍDUOS, POSIÇÕES SOCIAIS E IDENTIDADES CONSTRUÍDAS POR MEIO DO TURNEN NO RIO GRANDE DO SUL
}

\author{
Network Charactersn: individuals, social positions and identities built \\ through Turnen in Rio Grande do Sul
}

\author{
Alice Beatriz Assmann ${ }^{I}$ \\ Ester Liberato Pereira ${ }^{2}$ \\ Janice Zarpellon Mazo ${ }^{3}$
}

\begin{abstract}
RESUMO
Este estudo histórico cultural aborda as figurações e redes de interdependência do movimento Turnen, notadamente, em clubes e escolas teuto-brasileiras no estado do Rio Grande do Sul (RS), Brasil. Como prática cultural marcadamente germânica, o Turnen se desenvolveu em localidades do Rio Grande do Sul habitadas por imigrantes alemães e seus descendentes. Nesta direção, o objetivo deste artigo foi apreender as relações de indivíduos singulares e grupos estratégicos que ocuparam a rede diretiva de uma figuração do Turnen no Rio Grande do Sul, entre as décadas de 1870 e 1920. Afora a revisão bibliográfica, foram coletados e analisados indícios em documentos impressos, utilizando, como base teórica para a escrita dessa narrativa histórica, os preceitos da História Cultural e categorias da análise figuracional desenvolvidas pelo sociólogo Norbert Elias, especificamente, de figuração, redes de interdependência e equilíbrio de tensões. Por meio da interpretação dos indícios, evidenciaram-se grupos que ocuparam posições centrais, bem como unidades de indivíduos que ocuparam posições estratégicas dentro do grupo de pertencimento. Estes eram, frequentemente, homens teuto-brasileiros, compondo um universo masculino, que se pretendia como tal. O movimento Turnen, assim, era estruturado por meio do associativismo, em um modelo hierárquico de funções, no qual cada indivíduo pertencia a redes de interdependências, mas em constante dinâmica e oscilação. Portanto, nessa figuração, indivíduos assumiram determinados papéis sociais, a fim de manter o equilíbrio das tensões necessárias à manutenção do status quo desejado.
\end{abstract}

Palavras-chave: História; Ginástica; Esporte.

1 Professora dos cursos de Licenciatura e Bacharelado em Educação Física da Universidade do Estado de Minas Gerais (UEMG), Unidade Divinópolis. E-mail: alice.assmann@gmail.com.

2 Professora Colaboradora do Programa de Pós-Graduação em História (PPGH/Unimontes). Professora dos cursos de Bacharelado e Licenciatura em Educação Física da Universidade Estadual de Montes Claros - Unimontes. Coordenadora do Grupo de Estudos em História do Esporte e da Educação Física (GEHEF) do Laboratório de Estudo, Pesquisa e Extensão do Lazer (LUDENS). E-mail: ester.pereira@unimontes.br.

3 Professora da Escola de Educação Física, Fisioterapia e Dança (ESEFID) e do Programa de Pós-Graduação em Ciências do Movimento Humano (PPGCMH), da Universidade Federal do Rio Grande do Sul (UFRGS). E-mail: janice.mazo@ufrgs.br. 


\begin{abstract}
This historical cultural study addresses the figures and interdependence networks of Turnen movement, notably in clubs and schools in the state of Rio Grande do Sul (RS), Brazil. As a markedly German cultural practice, Turnen was developed in localities in RS inhabited by German immigrants and their descendants. In this sense, the objective of this article was to apprehend the relations of singular individuals and strategic groups that occupied the directive network of a Turnen figuration in Rio Grande do Sul, between the decades of 1870 and 1920. Apart from the bibliographic review, evidence was collected and analyzed on printed documents, using as theoretical basis for the writing of this historical narrative, the precepts of Cultural History and the categories of figurational analysis developed by the sociologist Norbert Elias, specifically of figuration, networks of interdependence and balance of tensions. Through the interpretation of the evidence, groups that occupied central positions were highlighted, as well as units of individuals who occupied strategic positions within the group of belonging. These are often German-Brasilian men, composing a male universe, which was intended as such. The Turnen movement, therefore, was structured through associativism, in a hierarchical model of functions, in which each individual belonged to networks of interdependencies, but in constant dynamics and oscillation. Therefore, in this figuration, individuals assumed certain social roles in order to maintain the balance of the tensions necessary to maintain the desired status quo.
\end{abstract}

Keywords: History; Gymnastics; Sport.

\title{
Introdução
}

$\mathrm{Na}$ contextura desta pesquisa, propõe-se uma narrativa histórica que busca conferir inteligibilidade a uma rede complexa: o movimento Turnen no Rio Grande do Sul (RS), Brasil. O Turnen, nesta pesquisa, é acompanhado de artigo masculino, pois é compreendido como um fenômeno que abrange um repertório mais amplo do que é possível apreender com a expressão "ginástica", como é comumente traduzido. Além das atividades sociais desenvolvidas nas e pelas sociedades de Turnen do Rio Grande do Sul, muitas introduziram, para além da ginástica, práticas esportivas como o tiro ao alvo, o bolão, o punhobol, a natação, o atletismo, o tênis e o futebol (ASSMANN; MAZO; SILVA, 2018; ASSMANN; MAZO, 2017; MAZO et al., 2012; KILPP, ASSMANN; MAZO, 2014). Ademais, como prática cultural, o Turnen, no mesmo passo em que representa, produz representações culturais de uma identidade étnica alemã e/ ou teuto-brasileira no sul do Brasil. Neste texto, entre os muitos arranjos que podem compor a 
teia de relações do Turnen, exploramos a sua figuração4 em clubes e escolas teuto-brasileiras. Mais especificamente, discorremos a propósito de personagens da rede e suas posições sociais na figuração do movimento Turnen no RS. Nomeadamente, expomos nomes e funções de personagens que participaram da rede diretiva dessa figuração, assinalada como um universo masculino, cujo elemento comum era ser homem, fundamentalmente, alemão ou teutobrasileiro5.

Como prática cultural marcadamente germânica, o Turnen se desenvolveu em lugares habitados por imigrantes alemães e seus descendentes. Este contingente migratório começou a chegar, ao sul do Brasil, em meados do século XIX, compondo colônias e núcleos de alemães em distintos locais do Rio Grande do Sul (ASSMANN, 2019). Nessas localidades, foram organizadas escolas e instituições clubísticas, dentre as quais salientamos as Turnverein ou, na tradução para o português, sociedades de ginástica, a partir dos anos de 1870 .

Perante tais considerações, este estudo objetiva apreender as relações de indivíduos singulares e grupos estratégicos que ocuparam a rede diretiva de uma figuração do Turnen no Rio Grande do Sul, entre as décadas de 1870 e 1920. A baliza temporal desta investigação abrange desde a emergência das instituições clubísticas de ginástica (WIESER, 1990) e a progressiva expansão de escolas criadas e mantidas por imigrantes alemães e seus descendentes, onde praticava-se o método ginástico alemão (KREUTZ, 1994), até a década de 1920, período pós-adversidades desencadeadas pela I Guerra Mundial (1914-1918). Nesse momento, embates acerca de um abrasileiramento das instituições teuto-brasileiras rondavam o imaginário social do Rio Grande do Sul (SEYFERTH, 2017; RAMOS, 2000) e um método oficial de ensino de Educação Física para as escolas brasileiras foi decretado: o método francês (MARINHO, 1980).

De modo a contemplar o objetivo proposto de compor uma narrativa historiográfica acerca da figuração do Turnen no RS e suas redes de interdependência (ELIAS, 1997; 2001), foi realizada uma revisão bibliográfica em livros, artigos, teses e dissertações a respeito do fenômeno analisado e coletados indícios em documentos impressos (LUCA, 2010; BURKE, 2004). Esta pesquisa insere-se no campo de investigação da História do Esporte e da Educação Física e pretendeu produzir um diálogo entre os preceitos da História Cultural - na qual se fundamenta nossa perspectiva historiográfica - e as categorias da análise figuracional desenvolvidas pelo sociólogo Norbert Elias, nomeadamente, de figuração, redes de interdependência e equilíbrio de tensões.

Os documentos impressos coletados foram atas, estatutos, edições comemorativas de aniversário das associações, de localidades, de festividades, e jornais. Os jornais impressos e os recortes de jornais eram redigidos em língua portuguesa e em idioma alemão no período da pesquisa. Os jornais $A$ Federação e A Discussão foram coletados a partir da plataforma da Hemeroteca Digital Brasileira. As reportagens do jornal Kolonie, veiculado inteiramente em idioma alemão até 1917, foram coletadas no acervo do CEDOC UNISC. Recortes de jornais,

4 Apesar de muitas traduções que definem o termo "Figuration", como cunhado por Norbert Elias, como "configuração", optamos, nesse estudo, por utilizar a tradução "figuração" (ELIAS, 1997; 2001).

$5 \mathrm{O}$ termo teuto-brasileiro é utilizado para designar os imigrantes e descendentes de alemães no Brasil. A fim de legitimar uma identidade teuto-brasileira, um conjunto de representações e símbolos foi apropriado pelos sujeitos que partilhavam tal identidade cultural étnica (SEYFERTH, 1992). Este conjunto foi chamado de germanismo, ou, Deutschtum. Desta forma, também sugere um discurso que busca a produção de um todo homogêneo, definindo o que está incluído ou excluído culturalmente do grupo. A língua, a religião, o Turnen, fazem parte desse discurso. 
fotografias, relatórios anuais, dentre outros documentos, foram coletados no acervo Benno Mentz do DELFOS - Espaço de Documentação e Memória Cultural da PUCRS. Quando possível, os indícios foram fotografados, sem flash, para preservação deles e posterior organização e manuseio. Dos exemplares coletados, foram selecionadas informações que condissessem com as categorias: Turnen, sociedade/clube de ginástica, escola alemã/teuto-brasileira.

Na teia que compõe a figuração do Movimento Turnen no RS, evidenciamos grupos que ocupam posições centrais, bem como indivíduos singulares que ocupam posições estratégicas dentro do grupo. Ainda encontramos personagens que fazem parte dessa engrenagem e que ocupam as posições sociais que lhes são possíveis dentro da figuração em que estão inseridos, o que não significa que tais posições não estejam permanentemente em tensão. As figurações, afinal, são compostas por "unidades de indivíduos relacionados entre si, ligados uns aos outros", por elos emocionais, culturais, políticos e sociais (ELIAS, 2001, p. 67). Embora com oscilações, o balanceamento do equilíbrio das tensões está constantemente sendo negociado. De tal modo, trata-se de desenhar linhas "de correlação entre os atos e realizações de atores da história, conhecidos por seus nomes, e a estrutura dos grupos sociais em que eles ganham sentido" (ELAS, 2001, p. 42). Os personagens que compõem os grupos e assumem posições de liderança na figuração do Turnen e, portanto, têm o papel de manter o status quo desejado são, frequentemente, homens, compondo um universo masculino, que se pretendia como tal.

$\mathrm{O}$ arcabouço da narrativa que expomos neste artigo, bem como suas divisões, procura decifrar os fios que compõem as redes da figuração do movimento Turnen no Rio Grande do Sul, a partir da interpretação das informações analisadas. A despeito do empenho para tal desígnio, salienta-se que, nessa rede, o embaraço dos nós e o emaranhado das conexões, próprios de um processo social complexo, tornaram a constituição da teia um desafio estrutural. Contudo, como estratégia de composição, determinamos dois tópicos, afora as concisas considerações iniciais e finais da pesquisa. No primeiro tópico, "Rede diretiva: um espaço de homens para homens", buscamos mostrar, ao(à) leitor(a), nomes e papéis de personagens que participaram da rede diretiva dessa figuração, distinguida como um universo masculino, cujo componente comum era ser homem, identificado como alemão ou teuto-brasileiro. No segundo, intitulado "Formação dos jovens alemães: é preciso aprender a liderar", procuramos abarcar arranjos e estratégias utilizados na formação dos jovens que deveriam ocupar papéis de liderança na figuração do Turnen. Assim, nos tópicos que seguem, apresentamos os resultados da operação historiográfica empreendida nessa pesquisa.

\section{Rede diretiva: um espaço de homens para homens}

A ginástica emergiu nos estados alemães como uma prática corporal que, além de ser vista como um meio de constituição de corpos fortes e saudáveis, seria capaz de unir uma nação. No início do século XIX, quando essa prática foi idealizada, a Alemanha não era um território unificado. Este processo apenas foi concluído no ano de 1871, com a fundação do Império Alemão, sob a liderança do Reino da Prússia. Nesse contexto, apareceram ideias e concepções sobre educação, unidade nacional, patriotismo e a vontade de lutar por uma pátria unificada. Dentre essas concepções, está o Turnen, como movimento comprometido politicamente e cujo objetivo central era preparar homens fortes para lutar pelo país (HOFMANN, PFISTER, 2004). 
$\mathrm{Na}$ historiografia alemã e brasileira acerca do Turnen, a figura mais afamada é Friederich Ludwig Jahn, reconhecido como Turnvater, o "pai da ginástica". A ginástica, a partir dos preceitos de Jahn, espalhou-se pelos estados alemães e culminou na criação de diversos espaços voltados à prática cultural do Turnen. Desde o seu estabelecimento e ao longo de décadas, eram nomeadas de Turnverein, termo do idioma alemão que, na tradução para a língua portuguesa, significa sociedade de ginástica. Para estas entidades associativas, assim como para aquelas fundadas no Rio Grande do Sul, tempos depois, Jahn era símbolo de uma identidade nacional alemã. Entre as práticas agenciadas nesses espaços, a ginástica era privilegiada pelos precursores das sociedades de ginástica, especialmente relacionada a discursos étnico-culturais. Contudo, como mencionado, outras modalidades foram apropriadas como possibilidade de prática esportiva no decorrer das décadas que perpassam esse estudo. A este encontro, vale a ressalva de Krüger (2013), em seu estudo acerca da ginástica e do esporte na Alemanha:

At this point, a short and summarising comment is appropriate with respect to the distinguishing terms of Turnen, gymnastics and sports. Turnen expressed the notion of bodily games and exercises in the tradition of Jahn's Turner movement. In this sense, everything, even English sports and games could be or become Turn-exercises and games. A precondition was that they were played in the spirit of German Turnerism for the people and the fatherland (KRÜGER, 2013, p.1595).

Tais práticas foram especialmente impulsionadas pela Turnverein mais antiga do estado do Rio Grande do Sul e que, até os dias de hoje, permanece em atividade, oferecendo diversos esportes para os associados. A primeira sociedade de ginástica do estado do Rio Grande do Sul foi inaugurada no dia seis de novembro de 1867, na capital Porto Alegre, denominada como Deutscher Turnverein de Porto Alegre (Sociedade Alemã de Ginástica de Porto Alegre). Em 1892, após reestruturações, esta entidade passou a responder pela denominação Turnerbund. Desde então, entidades voltadas para a prática da ginástica pelo método alemão (Turnen) espalharam-se por diferentes localidades do estado. Entre 1860 e 1920, Assmann (2019) contabilizou 34 sociedades de ginástica criadas e mantidas por imigrantes de descendentes de alemães no estado do Rio Grande do Sul. Estudos apontam para o associativismo teutobrasileiro como uma "mania" alemã (RAMBO, 2005), "um prazer em agrupar-se" (ROCHE, 1969) em entidades sociais. Para Mazo (2007, p. 494), as associações esportivas podem ser vistas "como um mecanismo de afirmação da identidade cultural teuto-brasileira" e expressão de uma consciência coletiva do grupo.

No final do século XIX, quando já havia certa quantidade de sociedades de ginástica espalhadas em localidades do Rio Grande do Sul, foi instituída a Deutsche Turnschaft von Rio Grande do Sul (Federação Alemã de Ginástica do Rio Grande do Sul), em 20 de outubro de 1895, pela iniciativa de J. Aloys Friederichs, então presidente da Turnerbund de Porto Alegre. A Federação tinha, como intuito, integrar as sociedades de ginástica, incrementar a organização

6 Neste ponto, um comentário breve e resumido é apropriado com relação aos termos distintivos de Turnen, ginástica e esportes. Turnen expressou a noção de jogos e exercícios corporais na tradição do movimento Turner de Jahn. Nesta direção, tudo, até esportes e jogos ingleses, podem ser ou se tornar exercícios e jogos de Turnen. Uma pré-condição era que eles fossem praticados no espírito do Turnerismo alemão para o povo e a pátria (KRÜGER, 2013, p.1595, tradução nossa). 
de novas e difundir representações culturais étnicas. Participaram da fundação desta entidade ${ }^{7}$, além da Turnerbund, as sociedades de ginástica de São Leopoldo, Lomba Grande, Novo Hamburgo, Santa Cruz e Campo Bom (GESCHICHTE..., 1929).

O movimento Turnen era estruturado por meio do associativismo, em um modelo hierárquico de funções, no qual cada indivíduo pertencia a determinadas redes de interdependências, mas em constante dinâmica e oscilação. Nessas redes, as funções de controle, comando e prestígio social eram ocupadas por homens. Até mesmo a ginástica, aos moldes de Jahn, pensada e executada primeiramente por eles, era um universo masculino. Ainda era uma figuração de indivíduos alemães ou "estrangeiros" aceitos no grupo, brancos, majoritariamente de boa condição financeira, e que se enquadravam nos padrões exigidos pelo grupo social. No movimento Turnen, no Rio Grande do Sul, encontramos, na direção e nos cargos oficiais das sociedades de ginástica, nomes e sobrenomes de homens alemães e/ou de seus descendentes. No período histórico demarcado para fins desse estudo, não foram evidenciadas, nos documentos acessados, mulheres nas posições de presidente, secretária, tesoureira, Turnwart ou Turnlehrer. Aquelas que eram citadas ocupavam funções de esposa, mãe, filha, acompanhante, praticante, além das poucas mulheres que se tornaram Vorturnerinnen (monitoras).

Na rede diretiva, a Turnerbund de Porto Alegre assumiu papel de centralidade, embora, oficialmente, esta representação fosse associada à Deutsche Turnerschaft von Rio Grande do Sul (Federação Alemã de Ginástica do Rio Grande do Sul), após o ano de 1895, quando se estabeleceu. Todavia, tal entidade era dirigida, especialmente, por indivíduos pertencentes à Turnerbund de Porto Alegre. Os indícios encontrados levam a crer que, através da Deutsche Turnerschaft, ${ }^{8}$ pretendia-se assegurar o equilíbrio de tensões, condição relevante para a manutenção do status quo e para os interesses do grupo central, vinculado à Turnerbund de Porto Alegre.

$\mathrm{Na}$ literatura consultada e, também, nos documentos analisados, um personagem aparece em saliência nas histórias da Turnerbund e da Turnerschaft: Jacob Aloys Friederichs. Personagem que, na figuração específica, assumia posição de poder no grupo central e, por conseguinte, na figuração do Turnen. Assim como assevera Sandra Pesavento (2004, p. 41), citando Pierre Bourdieu, Aloys Friederichs e a rede diretiva do movimento Turnen, no RS, detinham o "poder simbólico de dizer e fazer crer sobre o mundo", exercendo funções de controle sobre as atitudes, os comportamentos, os gostos, os valores e os papéis sociais adequados àqueles que pertenciam e/ou desejavam pertencer ao grupo. Através de representações culturais étnicas e modos específicos de coações, buscavam impor uma "maneira de dar a ver o mundo" e uma maneira de portar-se nesse mundo (PESAVENTO, 2004, p. 41).

Jacob Aloys Friederichs é apontado por diferentes autores (WIESER, 1990; TESCHE, 2011; HOFMEISTER, 1986; SILVA, 2005b) como principal incentivador do movimento Turnen, compreendido em sua singularidade enquanto prática cultural germânica no Rio Grande do Sul. Dentre os estudos localizados sobre Aloys Friederichs (1868 - 1950), destacamos a tese de Haike da Silva (2005b), a qual alude à sua biografia e ao papel desempenhado por

7 Consta, no Livro Comemorativo da VII Festa da Ginástica, datado de 1929, que as sociedades de ginástica das localidades de Taquara e Villa Germânia (Candelária) foram convidadas, mas que não compareceram na reunião (GESCHICHTE..., 1929). Apesar da existência de uma sociedade de ginástica que visava confederar as demais entidades coirmãs e comandar o movimento Turnen no Rio Grande do Sul, nem todas eram filiadas à Turnerschaft (FESTSCHRIFT, 1929). Dentre essas, mencionamos a Sociedade de Ginástica de Pelotas, fundada no dia sete de julho de 1896.

8 Em 1929, eram filiadas, à Federação, sociedades de ginástica de 15 localidades do Rio Grande do Sul. 
ele enquanto liderança associativa e étnica no sul do Brasil. Esta tese, no entanto, apresenta um cenário mais amplo acerca do associativismo e das histórias da Turnerbund de Porto Alegre. Como presidente da entidade por mais de $30 \operatorname{anos}^{9}$ (1892-1929), Aloys Friederichs é apontado como influência étnica, junto aos teuto-brasileiros, que proferia discursos de forte caráter germanista. Haike da Silva (2005b, p. 222) refere-se às décadas presididas por Aloys Friederichs, na Turnerbund de Porto Alegre, como um "reinado", construído sob a égide da afirmação identitária teuto-brasileira. Os vínculos com a pátria brasileira estavam, para ele, estreitamente ligados aos vínculos com a cultura alemã. Desse modo, ser um "bom brasileiro" significava ser um "bom alemão".

Jacob Aloys Friederichs imigrou ao Brasil em 1884, aos 16 anos de idade, chegando ao Rio de Janeiro e, posteriormente, a Porto Alegre, cidade que chamava de lar na "grande terra brasileira", como afirmou o imigrante (SILVA, 1997, p. 55). Em 1889, após a Proclamação da República, adquiriu cidadania brasileira, referindo-se ao Brasil como "Pátria adotiva", "lar escolhido e grangeado pelo trabalho", além de uma prova de "caráter e coração" (SILVA, 1997, p. 55). Seu pertencimento à comunidade de sangue, a alemã, foi, contudo, mantido e exacerbado em seus discursos, posicionamentos e atitudes. Segundo Silva (2005b, p. 150), o pertencimento à nação alemã estava fundamentado em dois princípios: "fidelidade e virtude". Esses princípios eram afirmados no modo de ser alemão, no uso do idioma, na manutenção dos costumes, na vitalidade física do alemão, na capacidade para o trabalho, [...] virtudes que deveriam ser cultivadas em favor da nova pátria, a pátria brasileira".

A posição de Aloys Friederichs enquanto líder da comunidade teuto-brasileira, no Rio Grande Sul, foi especialmente construída no associativismo ginástico. Ingressou como associado na sociedade de ginástica de Porto Alegre em 1888 e, desde então, foi se consolidando no meio comunitário "alemão" e assumindo uma posição social de liderança. Em 1892, foi tesoureiro e, já no ano seguinte, presidia a Turnerbund de Porto Alegre. Para Silva (2005b), o engajamento de Aloys Friederichs na sociedade de ginástica pode estar associado a modelos familiares, tendo em vista que o irmão mais velho já estava integrado à comunidade étnica alemã por meio de associações locais, como, também, pelo despertar do interesse através de festividades promovidas pela entidade ao público local. Ainda, as informações levam a crer que o desejo e a adesão de Aloys Friederichs à sociedade estão relacionados à pretensão de ascensão social através da representação de sujeito que é partícipe da "boa sociedade" local. E, além de partícipe, se coloca como a própria representação da "boa sociedade".

Friederichs não $\mathrm{p}$ arecia interessado em ser "apenas" um praticante de ginástica (ginasta) ou um associado "comum". Sua rápida ascensão no clube foi, também, uma escolha como sujeito singular por integrar posições sociais compreendidas como elevadas. Afinal, “a 'oportunidade de grandes realizações' individuais [...] dependeu durante muito tempo do fato de um indivíduo pertencer a grupos de elite específicos, ou da possibilidade de encontrar uma via de acesso a esses grupos" (ELAS, 2001, p. 42). Na sociedade ginástica, atuou em cargos administrativos, até alcançar o cargo máximo na instituição. Como líder da sociedade de ginástica da capital, fomentou a criação de uma instituição que congregaria as demais sociedades de ginástica, ficando os deveres e direitos dos associados de diversas localidades sob a sua tutela. Sua influência/poder se fortaleceu com a criação da Deutsche Turnerschaft

9 Foi presidente da Turnerbund nos seguintes períodos: 1893 a 1897; 1901 a 1914; 1917 a 1929 (SILVA, 2005b). 
von Rio Grande do Sul (Federação Alemã de Ginástica do Rio Grande do Sul), "instituição por meio da qual fazia alcançar seu discurso a outras sociedades do gênero no Estado" (SILVA, 2005a, p. 152). De tal modo, foi instituída uma entidade oficial de comando às sociedades de ginástica do estado, onde a liderança e as pretensões de Aloys Friederichs eram legitimadas e poderiam ser alastradas para outros espaços e indivíduos.

O papel social de Aloys Friederichs está intimamente ligado aos seus interesses pessoais. Silva (2005b) salienta o modo centralizador e paternalista com que tratava das atividades da sociedade de ginástica. As histórias do presidente/líder se emaranham às histórias da Turnerbund, processos que "caminham de mãos dadas" (ELIAS, 2001, p. 45); afinal, sociedade e indivíduo não são categorias que dizem respeito a "duas substâncias distintas e estáveis [...] independentes em sua existência" (ELIAS, 2001, p. 45). Um - a pessoa singular - influi no outro - a sua posição social, ou seja, as dinâmicas na posição social influem nas dinâmicas individuais, e vice-versa.

Além da Turnerschaft, Aloys Friederichs também fundou a Schwimmbadverband ${ }^{10}$ (Federação de Natação), em 1899, e a Bismarckrunde (Círculo de Bismarck), em 1909. Esta última caracterizava-se como uma associação destinada a "perpetuar a memória do "grande chanceler" (TELLES, 1974, p. 70), reunindo-se, anualmente, para celebrar o aniversário de Otto von Bismarck. Aloys Friederichs foi, também, atuante na Verband Deutscher Vereine (Federação das Sociedades Alemãs), entidade criada em 1886, que buscava garantir, através da organização do associativismo local, "a índole alemã", a germanidade e os "direitos tanto dos indivíduos como dos grupos" (RAMBO, 1999, p. 304). Outras sociedades, nas quais Aloys Friederichs fez parte da diretoria, são a Deutsche Hilfsverein (Associação Alemã Beneficente) e a Gemeinnützigerverein (Sociedade de Amparo Mútuo).

Como sócio honorário, consta, também, nas Turnvereine (sociedades de ginástica) de São Sebastião do Caí, Montenegro e Hamburgo Velho, do Club de Regatas Guahyba, da SchützenVerein (sociedade de atiradores) "Eintracht" de Cachoeira do Sul, da Sociedade Leopoldina de Porto Alegre, e, em 1928, se torna o primeiro alemão com residência no estrangeiro a ser contemplado como sócio honorário da Federação Alemã de Ginastas (Deutsche Turnerschaft). Além de tais distinções, também ganhou uma medalha de honra por seus serviços em prol da germanidade, em 1930, pela Verein für das Deutschtum im Ausland (Sociedade para a Germanidade no Exterior) (SILVA, 2005b). Sua posição social de liderança no associativismo ginástico e teuto-brasileiro proporcionava, a Aloys Friederichs, também, oportunidades de debates e pronunciamentos públicos pelo interior do estado. Nesses momentos, demonstrava deferência às ideias e preceitos difundidos por Friederich Ludwig Jahn, legitimado como o "pai da ginástica alemã" (Turnvater), e, por alusão a ele, "foi cognominado "pai da ginástica do Rio Grande do Sul” (SILVA, 2005b, p. 9). Tal simbologia atribuía, a Aloys Friederichs, uma representação soberana na figuração do Turnen. Sua liderança e sua função social eram asseguradas por essa representação.

As viagens de Aloys Friederichs à Alemanha, além de reforçar os laços de pertencimento à velha pátria, também fortaleciam a sua legitimidade como líder no Rio Grande do Sul. Tanto que, em 1914, em razão de seu retorno da Alemanha, foi organizado um Eilbotlaufen

10 Em Porto Alegre, no Rio Grande do Sul, foi construída a primeira piscina do país, em 1885, no Lago Guaíba, por iniciativa da Turnerbund, atual SOGIPA (ROCHA; WASKOW, 2017). 
(corrida de revezamento) em sua homenagem, com a participação de cinco entidades do estado (TURNWESEN, 11 mar. 1914). Percebe-se que a festividade para recepcionar Aloys Friederichs privilegia uma prática esportiva, a corrida (modalidade do atletismo); contudo, já fazia quase 50 anos desde a fundação, em 1867, da Turnerbund. Segundo Pfister (2011, p. 64), a Deutsche Turnerschaft da Alemanha resistia à introdução dos esportes nas sociedades de ginástica "por um lado, porque seus princípios contradiziam a aspiração dos turner ao condicionamento pleno e à orientação patriótica da população; por outro lado, contudo, também porque o esporte ameaçava o domínio do turnen na Alemanha".

A Turnerbund Porto Alegre começou a assumir uma posição favorável ao esporte, provavelmente, no princípio do século XX, mas com a ressalva de enaltecer, em primeiro lugar, o Turnen. No relatório de atividades da Turnerbund, datado de 1907, consta que o "sport" (esporte) retirava "forças juvenis" da sociedade (JAHRES-BERICHT..., 1907). Todavia, tal constatação era considerada apenas uma perda parcial, pois ele também se ocupava do cuidado e do exercício saudável do corpo. Segundo o texto, ambos se associavam muito bem e, assim, o esporte poderia ser recomendado para os jovens. O espaço dedicado aos esportes, na Turnerbund, pode ser aferido com a inauguração, em 1911, do seu Spielplatz (campo de jogos) no "subúrbio" (atual Bairro São João) da capital do RS, Porto Alegre (JAHRES-BERICHT 1911, 1912). O campo de jogos é exaltado como "um grande elemento do nosso Deutschtum local", destinado a constituir "um ponto de encontro aos domingos e dias de festa" (JAHRESBERICHT 1910, 1911, p. 4). Este espaço, segundo o “Operador” de Jogos, no período, Fritz H. Siegmann, estava reservado às seguintes práticas esportivas: Faustball (punhobol); Fussball (futebol); Tamborinball (Tamborim); Schleuderball; Kreisball; Drittenabschlagen e Krokett (croquet) (JAHRES-BERICHT 1911, 1912, p. 11).

Nesta época, quando identificamos indícios da apropriação de práticas esportivas pelo movimento Turnen, Aloys Friederichs estava à frente da Turnenbund. A representação de liderança de Aloys Friederichs entre as sociedades de ginástica é, também, atestada quando a diretoria da Sociedade de São Leopoldo o procura para pedir orientações quanto aos transtornos advindos da entrada do Brasil na I Guerra Mundial, em 1917 (MÜLLER, 1986). Conforme a ata de 27 de junho de 1917, apresentada por Müller (1986, p. 69), "quase dois meses depois, Aloys Friederichs informa que a Sociedade pode funcionar normalmente, pois Borges de Medeiros, Presidente do Estado, lhe afiançara que 'todas as sociedades teutas deveriam funcionar regularmente"". Aloys Friederichs era o "porta-voz" das sociedades, o mediador das decisões e o interventor junto aos líderes brasileiros e alemães. "No auge de sua liderança na década de 1920, como "o homem mais influente e ativo" no que se refere ao trabalho pelo bom relacionamento entre lusos e teutos, pela preservação da língua alemã e pela germanidade" (SILVA, 2005a, p. 309).

Proferia discursos e posicionamentos em prol da germanidade tanto em publicações escritas, em livros autobiográficos, brochura de canções, discursos impressos, ou através de correspondências, quanto em declarações e manifestações orais, na capital e na zona colonial do Rio Grande do Sul. Segundo Silva (2005a, p. 147-148), por meio de cartas trocadas entre Aloys Friederichs e pessoas influentes de diferentes regiões no sul do Brasil, bem como através do intercâmbio com pessoas no exterior, como Chile, Argentina e a própria Alemanha, "é possível perceber a constituição de uma rede de sociabilidade intelectual da qual fazia parte o personagem, rede esta que tinha o Deutschtum (germanidade) como foco de discussão".

A rede diretiva, através da Turnerschaft, adotou estratégias para o controle e a manutenção 
do movimento Turnen no Rio Grande do Sul e, dentre elas, se sobressaíram as festividades. Nestes eventos, era possível manifestar os preceitos e as diretrizes que deveriam ser seguidas pelos grupos pertencentes àquela figuração específica do Turnen, atingindo um grande e cativo público. Corrobora tal assertiva a preocupação da Deutschen Turnerschaft von Rio Grande do Sul em marcar, já na primeira reunião, um Festival de Ginástica Alemã (Deutsche Turnfest), que ocorreu, em 1896, no Prado Independência, posteriormente denominado Hipódromo Moinhos de Vento, situado em região identificada com a elite germânica de Porto Alegre. Nos eventos, as lideranças do movimento Turnen tinham a oportunidade de falar ao grande público acerca das "virtudes" e códigos que deveriam ser compartilhados pelo grupo. Na narrativa acerca da Turnverein de São Sebastião do Caí (DIE TURNERISCHE, 1938), após o campeonato de aniversário de 20 anos da sociedade de ginástica, foi registrado que o presidente da Turnerschaft, Aloys Friederichs discursou salientando o papel da entidade e de seus departamentos e "à toda sociedade desejou prosperidade". Sua fala traduz orgulho pela atuação da entidade na comunidade.

Nas celebrações das sociedades de ginástica, com algumas variações, no primeiro dia do evento, era realizada a recepção dos convidados, com músicas em alemão e apresentações, e pronunciado o discurso de abertura. Enquanto que, no dia seguinte, iniciava-se o torneio (QUITZAU, 2016), sendo o número de provas disputadas condicionado à infraestrutura da associação sede (LEVIEN; RIGO, 2013). Os eventos eram marcados por competições, apresentações e confraternização entre as sociedades de ginástica, exibindo-se exercícios livres, combinados, em aparelhos ${ }^{11}$ e exercícios denominados de populares. Tais exibições eram executadas pelos ginastas da entidade, separados em seus departamentos, treinados por um professor, instrutor ou monitor de ginástica, no decorrer de sessões semanais.

Nos festivais, conforme Levien e Rigo (2013), ainda que tivessem caráter competitivo, prevalecia o espírito de confraternização entre os indivíduos. No mesmo passo, Quitzau (2016, p. 134) afirma que eram considerados vencedores "todos aqueles que conseguiram atingir uma pontuação mínima determinada pela comissão organizadora e avaliadora do torneio". Para a autora (2016, p. 162), "a disputa estava muito mais atrelada à questão do desafio corporal, da participação, da certeza de ter realizado a melhor execução possível e ter representado a sua associação da forma mais nobre e fiel possível". Todavia, pondera-se que a forma de pontuação referida, possivelmente, estivesse presente em algumas entidades e/ou em determinado período e que fosse de interesse da rede diretiva construir um ideal de congregação em contraponto ao de confronto. No entanto, os indícios levam a crer que tal sistema estava, também, relacionado a um processo de aprovação dos sujeitos, ou seja, quem atingia o valor mínimo estipulado para cada exercício, era considerado apto, aprovado e constava na Siegerliste (lista dos vencedores), como encontrado em documentos das sociedades de ginástica. Ainda assim, os ginastas aprovados eram ranqueados por critério de desempenho, pois quando anunciadas as performances dos ginastas nas competições, apresentavam-se, muitas vezes, os nomes dos indivíduos e as respectivas pontuações em ordem decrescente, ou seja, o atleta com melhor desempenho aparecia na colocação " 1 " e, assim, sucessivamente. Logo, esta forma de apresentação dos resultados, sugere um ranqueamento, um ordenamento de posições de acordo com o melhor desempenho. Além disso, por vezes, eram entregues grinaldas de carvalho e

11 A ginástica em aparelhos é reconhecida como precursora da Ginástica Artística em aparelhos. 
diplomas aos primeiros classificados, enquanto os demais não recebiam a mesma honraria (GESCHICHTE..., 1929).

Segundo Quitzau (2016), a Turnerschatf exigia um rigoroso controle por parte do seu grupo de arbitragem e dos ginastas participantes nos torneios promovidos pela entidade. No Vater-Jahn-Gedenkpreis, realizado em Porto Alegre, em 1916, foi identificada e salientada "a falta de conhecimento dos exercícios e das novas formas de comando" por parte da arbitragem do torneio (QUITZAU, 2016, p. 75). Também, a partir da referência à "Turnverein Montenegro, cujos representantes teriam errado todos os afastamentos de pernas nos exercícios determinados para o torneio", a autora (2016, p. 75) aponta que a rede diretiva da Turnerschatf se preocupava com a correta execução dos movimentos e a atualização constante dos ginastas através dos periódicos específicos do Turnen.

A Turnverein Montenegro, citada no fragmento de texto acima, pertencia a uma das Gauen (comarcas), que compunham a planificação descentralizada da Deutsche Turnerschaft von Rio Grande do Sul. Deste modo, no ano de 1916, quando ocorreu o torneio supramencionado, a Turnverein Montenegro já estava agrupada com as sociedades de ginástica pioneiras no estado e de forte tradição (WIESER, 1990). Tendo em vista que a Turnerbund de Porto Alegre tinha um papel central no referido cenário, é provável que a crítica ao desempenho técnico pouco satisfatório dos ginastas da Turnverein Montenegro foi intensificada pela entidade. Ademais, consta a cobrança para que as associações adquiram "ao menos um jornal ginástico alemão (como o Deutsche Turnzeitung)" (QUITZAU, 2016, p. 75). Vale mencionar que a Turnerbund tinha acesso não apenas ao Deutsche Turnzeitung, mas a outros materiais impressos, como aqueles encontrados no acervo do Memorial SOGIPA.

A fim de sanar os problemas com a arbitragem, a diretoria da Turnerschaft assinalava a necessidade de preparo dos árbitros, "o que deveria acontecer através dos cursos de formação de instrutores de ginástica" (QUITZAU, 2016, p. 75). A formação desses ginastas, que aqui denominamos "monitores" (Vorturner), foi oficialmente iniciada, na Turnerbund, em 1901, quando foi criado o Vorturnerschaft (Liga dos Monitores de Ginástica), cuja liderança estava sob responsabilidade de Ernst Mitzscherlich (JAHRES-BERICHT..., 1907, p. 10). Foram, então, mantidos períodos de instrução, nos quais eram concedidas aulas práticas e teóricas. Wieser (1995, apud SILVA, 2005b) argumenta que o professor de ginástica era escolhido pelos associados, entre aqueles que eram "demonstradores" de ginástica, ou seja, os Vorturner. Tal designação é atribuída aos Vorturner, pois, além de ministrar aulas, em grandes eventos, por vezes, estes ginastas posicionavam-se à frente dos demais, frequentemente em cima de um palanque, juntamente com o Turnlehrer, Georg Black, a fim de demonstrar os movimentos, como pode ser visualizado em diferentes imagens coletadas (ASSMANN, 2019).

$\mathrm{Na}$ Vorturnerschaft, o líder fundador do departamento, Ernst Mitzscherlich foi visualizado em fotografia publicada no livro comemorativo de 150 anos da SOGIPA - como é chamada desde 1942 a Turnerbund de Porto Alegre - junto com os monitores de ginástica da Turnerbund em 1902: Walter Schilling, Arthur Schröter, Germano Sperb, Willy Mitzscherlich; Wilhelm Rösch e Henrich Rohde (ROCHA; WASKOW, 2017). Na referida imagem, as vestimentas utilizadas pelos ginastas têm cor clara, provavelmente branca, e, na camiseta, consta o símbolo das sociedades ginásticas - os 4F's - um cinto sobre as calças, com a mesma inscrição bordada, além da saudação "Gut Heil" (Salve; Boa saúde) e do nome da instituição - Turnerbund. O uniforme fornecia "toda uma gama de sinais" (ELIAS, 1997, p. 88), que localizava os personagens no seu meio social e as suas posições. 
"Uma grande mudança" ocorreu na Vorturnerschaft, em 1907, com a saída dos Vortuner Walter Schilling e Willy Mitzscherlich (UNSER VORTURNERSCHAFT, 1908, p. 5). O primeiro devido à profissão e o segundo para dar continuidade ao seu trabalho em Campinas, São Paulo. No relato, consta uma saudação - "Gut Heil" - à Turnverein de Campinas, que ganhou o "Treue Turnersmann" (confiável homem do Turnen). Essas informações permitem propor que a rede do movimento Turnen, no Brasil, compartilhava mais que representações culturais étnicas identitárias, mas também ocorriam realocações de indivíduos singulares entre as sociedades de ginástica. No mesmo ano, a Vorturnerschaft de Porto Alegre atraiu novos indivíduos aos cargos de monitores, a saber: O. Bachmann, A. Bohrer, E. Freitag, P. Krause, F. Siegmann e A. Homrich. No relatório anual de 1908, consta que, naquele ano, foram ministradas nove sessões de Vorturner, com onze períodos, os quais aconteceram aos domingos pela manhã, formando mais seis ginastas, com instrução prática e teórica (JAHRESBERICHT, 1909).

Ernst Mitzscherlich, fundador do departamento, designado como Ehrenvorturner (JAHRES-BERICHT, 1913), assim como Aloys Friederichs e Georg Black, também realizava viagens à "pátria mãe", Alemanha. Entre 1911 e 1912, Ernst Mitzscherlich esteve em território alemão. No seu retorno a Porto Alegre, também retomou seus trabalhos junto à sociedade de ginástica; contudo, segundo relatório das atividades de 1913, ele não conseguiu se manter como I Turnwart, devido a outros compromissos. A redação do relatório e os dados apresentados levam a crer que a escolha do I e II Turnwart (I e II) era realizada por votação nesse período (JAHRES-BERICHT, 1913). Como membro da diretoria, contudo, parece que, dentre os critérios para seleção do Turnwart, a condição era ser homem.

Na tese de Assmann (2019, p. 101) foi analisada uma fotografia, encontrada no Acervo Benno Mentz, do Instituto Delfos/PUCRS, que retratava um evento comemorativo, com alunos/ ginastas que praticavam Turnen junto à Turnerbund, provavelmente, datada da década de 1920 . À frente dos ginastas, devidamente alinhados, encontram-se, postos em um pequeno palanque, o professor Georg Black, realizando um sinal com o braço esquerdo, que empunha um objeto semelhante a uma batuta ${ }^{12}$, e, diante dele, um Vorturner (monitor) e uma Vorturnerin (monitora), provavelmente instruídos e selecionados devido à primazia na execução dos movimentos, o que os qualificava para realizar as demonstrações. Cabe mencionar que, a partir de 1904, algumas mulheres também receberam formação como monitoras de ginástica. Contudo, este número parece muito reduzido quando comparados aos homens.

Quanto à disposição dos alunos, existe uma clara separação entre homens/meninos e mulheres/meninas, estando elas posicionadas no centro. Tal arranjo irrompe na imaginação como a composição de uma orquestra, cujo maestro é Georg Black, o Vorturner e a Vorturnerin são os instrumentistas principais, e os demais alunos, aqueles que seguem os comandos do regente. Os alunos, bem como o professor, encontram-se uniformizados. O tom de festividade é marcado pela própria necessidade de registro e pela presença do grande público, possivelmente os pais e familiares das crianças e jovens que participavam da apresentação. Além disso, a prática simultânea de homens/meninos e mulheres/meninas também sugere um evento festivo. Percebe-se que, embora festivo, o evento denotava preocupação com a formação da juventude alemã e a propagação de valores como organização, disciplina, dentre outros, visando à

12 Instrumento utilizado por maestros de orquestras musicais. 
construção de futuras lideranças.

\section{Formação dos jovens alemães: é preciso aprender a liderar}

Georg Black, o professor, tantas vezes mencionado nos documentos encontrados, também ocupa posição social de liderança na figuração do Movimento Turnen no Rio Grande do Sul: um personagem que assumia uma função estratégica nas relações de interdependência. Sua atuação em instituições escolares e esportivas, por mais de 30 anos, conferiu a Georg Black o reconhecimento de precursor ou "pai da Educação Física no Rio Grande do Sul" (MAZO; LYRA, 2010, p. 968). Georg Black atuou, diretamente, em escolas de duas cidades, a saber: a) Porto Alegre: Ginásio Júlio de Castilhos, Ginásio Bom Conselho, Ginásio Rosário, Instituto Parobé, Seminário Evangélico de Professores, Colégio Anchieta, Colégio Farroupilha, Colégio Santa Maria, Colégio São José; e b) São Leopoldo: Colégio São José, Seminário Protestante, Sínodo Rio Grandense.

Ao encontro dos escritos de Elias (1997), Wieser e Leite (2005, p. 1) inferem que "como cidadão nascido num país reunificado a "sangue e ferro" sob o governo de Bismarck e que cresceu no tempo do alto imperialismo, ele não conseguia esconder seu orgulho por uma Alemanha dominante". Preservar as "virtudes alemãs", através da ginástica, do idioma, do trabalho, era necessário para uma Alemanha forte no "além mar". Exaltar a identidade alemã e o exercitar rigoroso do corpo eram meios de não se deixar "poluir" com os excessos da civilização, a "vaidade e o luxo".

Nascido em 1877, Georg Black emigrou da Alemanha para o Brasil em 1902. Com aproximadamente 15 anos de idade, entrou para a Sociedade de Ginástica de Munique como Zögling (iniciante), sendo efetivado como Vorturner (monitor de ginástica) após dois anos de prática, e, em 1896, tornou-se o dirigente dos Zöglinge. Depois de prestar serviço militar, obteve seu certificado de professor de ginástica - Turnlehrer - junto à Königlich Bayerische Zentral-Turnlehrer-Bildungsanstalt (Escola Central Bávara para Professores de Ginástica), na Alemanha. No mesmo ano, partiu para o Brasil a fim de fundar uma "Nova Munique" em um lugar que prometia prosperidade (WIESER; LEITE, 2005).

Logo, no ano de 1903, Georg Black tornou-se sócio da Turnerbund, participando do IV Turnfest der Deutschen Turnerschaft von Rio Grande do Sul (IV Festival de Ginástica da Federação Alemã de Ginástica do Rio Grande do Sul). Diferenciava-se tecnicamente dos demais ginastas junto a volkstümlichen Wetturnen (ginástica popular de competição), atividade que "envolvia arremessos, saltos em altura e em distância, além de corridas; fazia parte do movimento do Turnen que, posteriormente, tornou-se conhecido como atletismo" (MAZO; LYRA, 2010, p. 969). Vinculou-se, também, ao clube de ciclismo e ao recém-criado Grêmio Foot Ball Porto Alegrense (1903), primeiro clube de futebol da capital (MAZO; LYRA, 2010). Georg Black também é identificado como responsável pela introdução de práticas como a natação, o punhobol, o Tamburinball, a corrida de revezamento, o atletismo. Através da sua atuação na Turnerbund e da rede de indivíduos com que se relacionava, também ajudou a propagar estas práticas em outras localidades do Rio Grande do Sul.

Assim como Aloys Friederichs, Georg Black dedicou-se a escrever sobre suas ideias e conhecimentos acerca do Turnen. Como redator chefe do Deutsche Turnbläter (Folha de 
Ginástica Alemã), produzido pela Turnerbund, desde 1916, produziu textos sobre o Modern Leichtatletik (atletismo moderno) (MAZO; LYRA, 2010). O discurso sobre o atletismo foi, provavelmente, exaltado após visita de estudo na Alemanha, em 1913, onde participou, também, de competições de Leichtathletik (atletismo). Na ocasião, Georg Black participou das disciplinas de arremesso de peso (Kugelstossen), salto em distância (Weitspringen), corrida de cem metros, corrida de 10.000 metros e natação, obtendo "grande êxito", segundo o relato de sua empreitada (JAHRES-BERICHT, 1914, p. 3). O Turnlehrer foi um grande incentivador das práticas do atletismo, que, de certa forma, estava presente nas atividades ginásticas desenvolvidas nas sociedades desde fins do século XIX.

No texto em homenagem aos 50 anos de idade de Georg Black, publicado no livro da Stiftungfest de 1927, da Turnerbund Porto Alegre, Aloys Friederichs conta como descobriu que o "jovem Black" era possuidor de certificação específica para atuar como professor de ginástica. Em 1905, a Turnerbund precisava encontrar urgente um "professor certificado" e foi quando Georg Black contou que possuía tal especialização de cursos feitos na Alemanha. Segundo a narrativa de Aloys Friederichs (1927, s/p), Georg Black pretendia, ainda, ser o colonizador, cofundador, de Nova-Munique, "o que para nossa felicidade não aconteceu, se não, não seria o nosso Black". Segue contando: "estava no seu pior momento na procura e apelação por um diplomado Turnlehrer, então me procura este, por nós não procurado, e também não encontrado, Turnlehrer Black com sua "Patente", em meu porão, na rua Aurora, e me deixa o mais importante documento."

Entre 1903 e 1906, Georg Black foi Vorturner e II Turnwart da entidade de Porto Alegre. Após a constatação de sua certificação, passou a ser o Turnlehrer, responsável pelas aulas de ginástica de todos os departamentos, no decorrer dos 30 anos em que exerceu seu cargo na Turnerbund. Conforme Wieser e Leite (2005, p. 1), com a efetivação de Georg Black, a Turnerbund Porto Alegre "não ganhou apenas um professor de ginástica qualificado e experiente, mas também, como ficou claro com o passar do tempo, um amigo de todos os esportes, um incentivador do esporte escolar e um educador, que facilmente entusiasmava os jovens com o seu trabalho".

Em 1906, quando Georg Black deixou sua posição de Turnwart e assumiu como Turnlehrer (professor de ginástica) da Turnerbund, foi atribuída a ele a responsabilidade pela direção técnica, bem como pela formação inicial e continuada dos monitores da Vorturnerschaft (TURNER-BUND, 1917, p. 10). Os dados, contudo, indicam que ele já atuava na formação dos Vorturner em período anterior. Segundo o relatório anual de 1904, "a fim de complementar os conhecimentos e as capacidades teóricas e práticas da ginástica", foi ofertada formação complementar nos meses de inverno aos Vorturner e aos Anmänner, sob a direção do II Turnwart, Georg Black. Como integrantes da Vorturnerschaft, foram nomeados, naquele ano, como Vortuner, os Anmänner Adolf Wink, Wilhelm Bräscher, Carl Oderrich e R. Weinheber, e como Anmänner, os ginastas Alfons Bohrer e Herman Ruhl (DIE VORTUNERSCHAFT, 1905). Pode-se aludir que a categoria Anmänner referia-se aos ginastas em posição de prémonitoria, ou seja, possivelmente antes de tornar-se Vorturner, era necessário formar-se como Anmänner.

Para além da sua atuação junto à formação de instrutores de ginástica no Rio Grande do Sul, Georg Black é reconhecido como o precursor do escotismo no Brasil, fundando o primeiro grupo de escoteiros em 1913 (MAZO; LYRA, 2010). A ideia para tal formação parece ter surgido após retornar de uma viagem que fez à Alemanha, onde participou da 
celebração do Völkerschlachtdenkmal (Memorial da Batalha dos Povos) na "velha pátria" (DIE PFANDABTEILUNG..., 1917, p. 21), além de festividades junto a instituições de Turnen alemãs, oportunidade em que conheceu a prática do escotismo. Destaca-se que, nos tempos em que esteve na Alemanha, Georg Black esteve em Munique, participando de um curso de aprimoramento teórico e prático acerca do Turnen (UNSER TURNBETRIEB, 1914, p. 4). E, neste mesmo período, em março de 1913, foi anunciada a criação de um grupo de escoteiros na Sociedade de Ginástica de Munique (QUITZAU, 2019). Logo, tais evidências levam a crer que estes conhecimentos estavam em voga naquele espaço-tempo e, possivelmente, fizeram parte dos conteúdos abordados no referido curso.

Assim como Wieser e Leite (2005), Mazo e Lyra (2010) e Quitzau (2019) também destacam que, para Georg Black, o escotismo e sua severidade eram uma forma de manter os jovens, o futuro da nação e do Deutschtum, longe dos perigos e das tentações citadinas. Nas palavras de Wieser e Leite (2005, p. 2), o Turnlehrer evocava o "controle sobre si mesmo", sobre seus atos e sobre seu corpo, salientava a importância "das privações e abdicações". Os discursos pela ordem, subordinação e disciplina eram também salientados em textos redigidos pela sociedade ginástica a fim de "convencer os pais sobre a importância de se começar a prática da ginástica desde cedo" (QUITZAU, 2016, p. 189). Para Quitzau (2019, p. 16), o escotismo deveria servir como um "complemento ao ensino escolar". Ao encontro de tais evidências, supomos que, se para Georg Black o controle era um preceito do escotismo, assim o deveria ser também para as demais atividades. Logo, se tomarmos por base a severidade com que era desenvolvida a prática do escotismo, podemos crer que as aulas de ginástica também eram regradas pela máxima da disciplina, do rigor das atitudes e dos movimentos. Aliado a isto, Rudolf Falk, em entrevista para Telles (1974, p. 94), lembra que o "regulamento da escola era muito severo; reinava uma disciplina férrea", ao tratar da Hilfsvereinschule ${ }^{13}$.

No escotismo, atividades que exigiam grande esforço físico e psicológico eram utilizadas como instrumentos para a promoção de mecanismos de autorregulação ou autocoação. Um modo de treinamento que se assemelha àquele discorrido por Elias (1997), acerca das confrarias nacionalistas, voltado para o controle dos impulsos, a formação de uma estrutura psicológica que depende, em grande medida, de uma coação externa, "um cordão umbilical [...] que incluía uma hierarquia estritamente formalizada de níveis de comando" (ELIAS, 1997, p. 95). Nessa engrenagem, o Turnlehrer, Georg Black, assumia uma posição de poder que o situava como líder nas relações sociais interdependentes do movimento Turnen no Rio Grande do Sul, especialmente no que concerne à ginástica nas escolas.

Não obstante, a pregação pela ordem e disciplina, algumas passagens transcritas por Telles (1974) acerca do processo de ensino e aprendizagem da Hilfsvereinschule, indicam que os meninos também se rebelavam contra a rigidez empregada pelos professores. Segundo Telles (1974, p. 84), o Prof. Rösch, Vorturner, responsável pelas aulas de ginástica na escola, em 1904, "se queixava da indisciplina reinante" na instituição. Outra passagem refere que, alegando desobediência por parte de um aluno, o professor Köhling, da mesma instituição, espancou "barbaramente" um aluno no campo de jogos (TELLES, 1974, p. 83). A postura do professor foi reprimida e ele se afastou da instituição após o incidente, que repercutiu na proibição de castigos corporais.

13 Atual Colégio Farroupilha, de Porto Alegre. 
Dentre as atividades realizadas pelos escoteiros, salientamos o Jamboree, como são denominados os acampamentos realizados por estes grupos. Em um acampamento organizado e sediado pela Turnverein Cahy, com a participação dos grupos de Porto Alegre, Santa Cruz, São Leopoldo e Montenegro ${ }^{14}$, são encontradas atividades que permitem compor uma imagem mental acerca desse arranjo, no período específico. O programa do evento está escrito em ambos os idiomas, português e alemão. O cronograma estende-se de seis a onze de setembro de 1927, ou seja, seis dias de programação. Após um dia reservado à recepção dos escoteiros das localidades supramencionadas, o evento era iniciado com um culto na igreja evangélica - evidenciando a proximidade do clube com tal confissão religiosa - seguido de uma passeata pelas ruas da Vila. A tarde seria destinada aos "exercícios physicos ao ar livre no campo da Turnverein Cahy", enquanto, à noite, estava programada uma festividade na sede local (TURNVEREIN CAHY, 1927). No terceiro dia, seria montado, de fato, o acampamento no campo da própria instituição. A programação seguia com a inauguração da bandeira dos escoteiros e um "combate simulado dos escoteiros"; em idioma alemão, essa atividade era denominada como Kriegspiel (Jogo de Guerra). Outras práticas eram danças e cantos populares previstos para o turno da noite.

No planejamento do dia seguinte, chama a atenção as diferenças das traduções redigidas no programa, ocasionando, inclusive, alteração de sentido quando a atividade mencionada é revertida do português ao alemão. No português, consta "exercícios do escotismo (Vida dos Escoteiros)", enquanto que, no alemão, encontramos "Wettbewerb in Pfanderfertigkeiten", ou seja, "competição nas competências escoteiras". À tarde, a programação previa "diversões", em idioma português, e "danças folclóricas e cantos", em idioma alemão. Enquanto que, à noite, seria realizada uma marcha noturna, seguida de um grande "bivaque", ou, uma grande "fogueira", conforme consta em idioma alemão. O último dia estava destinado para visitação da fábrica de Carlos $\mathrm{H}$. Oderich e Cia, seguida de uma homenagem à bandeira nacional brasileira e um festival na Liga Sportiva, à noite.

Este evento - Jamboree de 1927 - foi citado no relato acerca do grupo de escoteiros de São Sebastião do Caí, redigido em 1938. A breve citação destacou a participação "do fundador do escotismo, Georg Black" (PFANDFINDERGRUPPE, 1938, p. 68). O grupo de escoteiros (Pfandfindergruppe) da Turnverein de São Sebastião do Caí foi oficialmente instituído em março de 1917, por sugestão de Eduard Kuminsk, durante assembleia na Turnverein local. Como Oberfeldmeister (mestre de campo chefe) do grupo, foi nomeado A. Grundmann, Feldmeister (mestre de campo) ${ }^{15}$ A. Trein, W. Trein, F. Patro e, como tesoureiro, E. Kuminsky. Diferentemente do que parece ter sido instituído ou intencionado por Georg Black na Turnerbund, à filiação ao grupo de escoteiros de São Sebastião do Caí era necessário arcar com uma mensalidade no valor de 500 rs. (PFANDFINDERGRUPPE, 1938).

Contudo, o texto afirma que, muito antes da organização de um grupo de escoteiros

14 Em Montenegro, o grupo de escoteiros foi criado em 1927 sob a liderança de P. Wilhelm Scheerer e Ludwig Groger e, em 1929, contava com 40 integrantes (TURNVEREIN SÃO JOÃO..., 1929).

15 Não conseguimos apurar, especificamente, as responsabilidades de cada um destes personagens - Oberfeldmeister e Feldmeister - na figuração do escotismo. Cabe mecionar que, no livro comemorativo aos 25 anos da Turnerbund, publicado em 1917, Kolfhaus consta como Oberfeldmeister (mestre de campo chefe) do grupo de escoteiros da referida entidade, enquanto que Gerog Black consta na posição de Feldmeister (mestre de campo) (DIE PFANDABTEILUNG..., 1917, p. 22). Contudo, Georg Balck é quem parece acompanhar os meninos em suas atividades e atuar de forma mais acentuada na manutenção do grupo. 
na Turnverein, já existiam atividades escoteiras para os ginastas. Cita, então, a primeira viagem (Fahrt), realizada dia 10 de outubro de 1915, com meninos e seis adultos da sociedade ao Mariasinha Berg (Morro da Mariasinha), próximo a Montenegro. Na noite anterior, os participantes se encontraram no Turnhalle e, "pontualmente", às 9h da noite, foram para suas camas, onde deveriam "ficar em silêncio" (PFANDFINDERGRUPPE, 1938, p. 66). Às 3h da manhã, acordaram; às $4 \mathrm{~h}$, tomaram café da manhã e, pontualmente, às $5 \mathrm{~h}$, cruzaram a cidade ${ }^{16}$ cantando. Às 7h40min, chegaram a Parecy, onde descansaram por meia hora. Até a ponte Eisenbahn, sobre o Rio Caí, caminharam mais $1 \mathrm{~h}$ e $20 \mathrm{~min}$. "Com brincadeiras e cantos o tempo passou rapidamente" e, quando "o relógio da igreja marcava $8 \mathrm{~h}$ da noite, estavam todos, novamente, no Turnhalle". A pequena viagem foi liderada pelo Turnwart Kuminsky e "com grande prudência por ele ordenado" (PFANDFINDERGRUPPE, 1938, p. 66).

A fim de conhecer o grupo de escoteiros da Turnerbund de Porto Alegre, foi realizada uma visita, à capital, nos dias 4 e 5 de setembro de 1915. Nesta ocasião, os membros da entidade de São Sebastião do Caí foram recepcionados por 30 meninos escoteiros, com idades entre 10 e 15 anos, e pelo professor Georg Black. A viagem sugere tanto a proximidade dos professores - Kumisky e Black - quanto a percepção da Turnerbund enquanto modelo. Ainda é possível propor o interesse da Turnerbund na criação de outros grupos de escoteiros em localidades próximas, a fim de compartilhar eventos.

Segundo Quitzau (2019), os grupos de escoteiros do Rio Grande do Sul apresentavamse como uma particularidade no Brasil e mantinham relações muito mais fortes com grupos coirmãos da Alemanha do que com grupos de escoteiros de outras regiões do Brasil. Contudo, os dados apresentados nessa pesquisa indicam que os grupos de escoteiros, vinculados às sociedades de ginástica do Rio Grande do Sul, mantinham relações de proximidade, realizando excursões e atividades interclubes. Em junho de 1917, por exemplo, cinco escoteiros - João Paternoster, de Caxias, Germano Noll, de Nova Palmira, Carlos H. Feix, de Kronenthal, Affonso Rossler, de Feliz, e Frederico Muller, de Cahy - juntamente com W. Trein, A Dill, O. Weber, W. Kayser e Ed. Kummisky, empreenderam uma marcha de $65 \mathrm{~km}^{17}$, por 14 horas, entre Caxias e Caí. Acerca do grupo de escoteiros local, o texto alude: "Junto aos pequenos espertos, incluindo alguns trajetos de $100 \mathrm{~km}$, não se percebe fadiga. O Sr. Kuminsky elogiou a obediência e a ordem do pequeno bando, que também causou uma boa impressão aos externos" 18 (PFANDFINDERGRUPPE, 1938, p. 67).

Além dos grupos de Porto Alegre, São Sebastião do Caí e Montenegro, em Santa Cruz do $\mathrm{Sul}^{19}$, um grupo de escoteiros, com 108 meninos, foi criado em 1916, sob o comando do Pastor Lechler como Oberfeldmeister e de João Lipinsky, instrutor de ginástica da entidade, como Feldmeister. A presença de um pastor evangélico na direção do grupo indica uma afinidade

16 No texto, é utilizada a expressão entre aspas "zum "städtle" hinaus", possivelmente em referência a uma canção popular chamada "Muss i denn zum Städtle hinaus", escrita por Friedrich Silcher. Tal referência pode sugerir que esta fosse uma das canções proferidas pelos escoteiros.

17 Distância referida no documento (PFANDFINDERGRUPPE, 1938).

18 Bei den kleinen Kerlchen, darunter sich einige befanden 100km lange strecke nichts von Ermuedung merken. Herr Kuminsky lobte den Gehorsam und Ordnung der kleinen Schar, die auch auf die Fremden recht guten Eindruck machte.

19 Em 26 de janeiro de 1917, foi criada a deutschbrasilianische Pfadfinderbunde für Rio Grande do Sul (Liga Teuto-brasileira de Escoteiros do Rio Grande do Sul) pelos grupos de escoteiros de Santa Cruz, São Sebastião do Caí e Porto Alegre (DIE PFANDABTEILUNG..., 1917, p. 21). A data é dúbia, contudo, tendo em vista a data oficial de fundação do grupo de São Sebastião do Caí. Quitzau (2018) também encontrou indícios de grupos de escoteiros em Taquara e Lajeado. Contudo, não apresentou evidências que sustentam a relação entre os grupos - exceto de Porto Alegre - com as sociedades de ginástica locais. 
da instituição de ginástica com tal confissão religiosa. Ainda manifesta o papel disciplinar de tal instituição, tendo em vista a ligação do escotismo à educação dos "jovens alemães" (TURNVEREIN SANTA CRUZ, 1929).

Mesmo antes da criação dos primeiros grupos de escoteiros nas sociedades de ginástica do Rio Grande do Sul, a formação de jovens conscientes de sua posição social já era uma preocupação. Assim, foi oportunizado, em 1910, aos meninos das classes superiores de ambas as escolas, que praticavam ginástica na Turnerbund (Hilfsvereinschule e St. Josephschule), participar de um Riege (grupo de ginástica), com um período semanal de estudos para Vorturner (monitor de ginástica). Segundo o relato acerca de tal arranjo, esta formação visava educar "os jovens ginastas desde cedo para tomar decisões e lidar com as situações de forma independente, como se eles também dessem ordens e a se submeter livremente e alegremente a aprender com os seus camaradas"20 (SCHRÖTER; BLACK, 1911, p. 13).

Tomar decisões, obedecer às normas sociais impostas - e impor obediência aos demais -, disciplinar as condutas, controlar os instintos, assumir determinadas atitudes, portar-se de forma específica, são alguns códigos de comportamento que deveriam ser incorporados ao habitus desses meninos. Um conjunto de "normas e valores, cujos mandamentos são obrigatórios para os indivíduos" (ELIAS, 1997, p. 85), particulares a essa figuração. Tal conjunto representava esse grupo e o distinguia de outros; logo, eram necessários à manutenção de sua posição no entrelaçamento social.

\section{Considerações Finais}

Nesse estudo, salientamos a rede diretiva de uma figuração do Turnen no Rio Grande do Sul, composta por unidades de indivíduos interdependentes. Neste contexto complexo, os indivíduos tomam posições sociais e encontram-se inseridos em relações, as quais permanecem de forma socialmente interdependente. As posições sociais e as suas apropriações fundamentam atitudes, sentimentos e códigos de comportamento que buscam a manutenção do status quo determinado e almejado pelo grupo. Na figuração do Turnen, no caso do Rio Grande do Sul a preservação e a exaltação de uma identidade étnica teuto-brasileira perpassava as ações, representações e apropriações compartilhadas pelo grupo.

$\mathrm{Na}$ busca pela conservação do equilíbrio indispensável de tensões, determinados personagens adquiriram posições de poder distintas: os líderes das sociedades de ginástica, em particular, o líder do grupo central - Jacob Aloys Friederichs - e os professores, instrutores, monitores que ministravam as aulas, os treinamentos, preparavam e disputavam torneios e, nesse grupo, em especial, Georg Black, também professor da Turnerbund. Ressalta-se que, embora a ginástica fosse o pilar das práticas corporais no princípio da organização das sociedades de ginástica, gradualmente, os discursos dos líderes estabeleciam ligações com o universo dos esportes. A partir de estratégias de formação, em grupos específicos, com técnicas de autodisciplina e obediência, buscava-se, também, a preparação dos jovens meninos alemães

20 [...] die jungen Turner frühzeitig zu entschlossenem uns selbständigem Handeln, wie sie sich aber auch einem gegebenen Befehle und sei er vom eigenen Kamaraden aus, freiwillig und freudig zu unterwerfen lernen. 
para o desempenho das suas funções perante a sociedade do Turnen.

Conforme evidenciado nesse estudo, às mulheres não era concedido acesso à rede diretiva do Turnen. Elas faziam parte de um grupo minoritário nessa figuração. Indivíduos (homens) assumiram determinados papéis sociais, a fim de manter o equilíbrio das tensões necessárias à manutenção da figuração. Esses papéis eram internalizados por seus personagens e deliberados em uma relação de dependência com todos os demais que participavam das composições, tanto de modo restrito, quanto de modo mais amplo.

Salienta-se que, a despeito da reverência ao grupo principal e suas lideranças, e da criação de códigos que deveriam - ou tensionavam - ser compartilhados por todos, cada entidade deve ser compreendida em sua característica, como um arranjo que, embora coeso com a rede, é também singular, com ações, interesses e negociações próprias. Afinal, os indivíduos que compõem essa trama são relativamente autônomos, bem como dependentes em relação uns aos outros. Diante de tais evidências, sugere-se a realização de mais estudos sobre as sociedades de ginástica organizadas em outras regiões do Brasil, para que, no futuro, possamos avançar nas pesquisas históricas de cunho comparativo.

\section{Referências}

ASSMANN, Alice Beatriz. Figurações do Turnen no sul do Brasil: redes de interdependência em escolas e clubes (décadas 1870-1920). 211 f. 2019. Tese (Doutorado em Ciências do Movimento Humano). Universidade Federal do Rio Grande do Sul. Porto Alegre, 2019.

ASSMANN, Alice Beatriz; MAZO, Janice Zarpellon. Turnen: para além da ginástica: configurações dinâmicas em um espaço de práticas esportivas. Revista Brasileira de Educação Física e Esporte, São Paulo, v. 31, n. 2, 2017, p.489-503.

ASSMANN, Alice Beatriz; MAZO, Janice Zarpellon; SILVA, Carolina Fernandes da. SPORT: uma concepção emergente no jornal Kolonie. Motrivivência, Florianópolis, v. 29, n. esp., 2017, p. 77-91.

BURKE, Peter. Testemunha ocular: história e imagem. Bauru: Educs, 2004.

DIE PFANDABTEILUNG des Turnerbundes Porto Alegre. TURNER-BUND Porto Alegre (1892-1917). Livro comemorativo 25 anos, Turnerbund, Porto Alegre, 1917. Encontrado no Acervo Benno Mentz, Instituto Delfos/ PUCRS.

DIE TURNERISCHE entwicklung des Turnverein Cahy, São Sebastião do Caí. Compilação de textos, 1938. Encontrado no Acervo Benno Mentz, Instituto Delfos/PUCRS.

DIE VORTUNERSCHAFT. Jahres-Bericht des "Turner-Bundes" zu Porto Alegre. Relatório anual, Turnerbund, Porto Alegre, 30 jan. 1905. Encontrado no Acervo Benno Mentz, Instituto Delfos/PUCRS. 
ELIAS, Norbert. Os Alemães: a luta pelo poder e a evolução do habitus nos século XIX e XX. Rio de Janeiro: Jorge Zahar Ed., 1997.

ELIAS, Norbert, $A$ sociedade da corte: investigação sobre a sociologia da realeza e da aristocracia de corte. Rio de Janeiro: Jorge Zahar Ed., 2001.

FESTSCHRIFT von der VII Turnfest der Turnerschaft von Rio Grande do Sul. Livro Comemorativo. Porto Alegre: Martin Fischer, 1929. Encontrado no Centro de Documentação da UNISC.

FRIEDERICHS, Jacob Aloys. Unser 50-jähriger Black. Livro comemorativo, Turnerbund, Porto Alegre, 23 ab. 1927. Encontrado no Centro de Documentação da UNISC.

GESCHICHTE der Turnerschaft von Rio Grande do Sul. Festschrift von der VII Turnfest der Turnerschaft von Rio Grande do Sul. Livro Comemorativo. Porto Alegre: Martin Fischer, 1929. Encontrado no Centro de Documentação da UNISC.

HOFFMEISTER FILHO, Carlos Bento. Doze Décadas de História. Porto Alegre: Editora Palloti, 1987.

HOFMANN, Annette R.; PFISTER, Gertrud. Turnen - a Forgotten Movement Culture: Its Beginnings in Germany and Diffusion in the Unites States. In.: HOFMANN, A. R. Turnen and Sport: Transatlantic transfers. Münster: Waxmann Verlag Gmbh, 2004.

JAHRES-BERICHT 1910. Relatório anual, Turnerbund, Porto Alegre, 30 jan. 1911. Encontrado no Acervo Benno Mentz, Instituto Delfos/PUCRS.

JAHRES-BERICHT 1911. Relatório anual, Turnerbund, Porto Alegre, 31 jan. 1912. Encontrado no Acervo Benno Mentz, Instituto Delfos/PUCRS.

JAHRES-BERICHT 1912. Relatório anual, Turnerbund, Porto Alegre, 30 jan. 1913. Encontrado no Acervo Benno Mentz, Instituto Delfos/PUCRS.

JAHRES-BERICHT 1913. Relatório anual, Turnerbund, Porto Alegre, 21 jan. 1914. Encontrado no Acervo Benno Mentz, Instituto Delfos/PUCRS.

JAHRES-BERICHT des "Turner-Bundes" zu Porto Alegre. Relatório anual, Turnerbund, Porto Alegre, 30 jan. 1907. Encontrado no Acervo Benno Mentz, Instituto Delfos/PUCRS.

JAHRESBERICH, des "Turner-Bundes" zu Porto Alegre. Relatório anual, Turnerbund, Porto Alegre, 30 jan. 1909. Encontrado no Acervo Benno Mentz, Instituto Delfos/PUCRS.

KILPP, Cecília Elisa; ASSMANN, Alice Beatriz; MAZO, Janice Zarpellon. Turnverein Estrela: ginástica e 
esportes. Revista Contemporânea - Dossiê História e Esporte, ano 4, vol.2, 2014.

KREUTZ, Lúcio. Escolas da imigração alemã no Rio Grande do Sul: perspectiva histórica. In.: MAUCH, Cláudia; VASCONCELLOS, Naira. Os Alemães no sul do Brasil: cultura, etnicidade, história. Canoas: Ulbra, 1994.

KRÜGER, Michael. The History of German Sports Clubs: Between Integration and Emigration. The International Journal of the History of Sport, v.30, n.14, p.1586-1603, 2013.

LEVIEN, Ana Luiza Angelo; RIGO, Luiz Carlos. Considerações sobre o "Turnfest" e "Gauturnfest" no Rio Grande do Sul (1890-1930). Revista Didática Sistêmica, II Extremos do Sul - Edição Especial, p. 159-176, 2013.

LUCA, T. R. História dos, nos e por meio dos periódicos. In: PINSKI, C. (Org.). Fontes históricas. São Paulo: Contexto, 2010, p. 23-80.

MARINHO, Inezil Penna. Estudo da evolução dos principais sistemas e métodos ginásticos de Educação Física adotados no Brasil. In.: I Simpósio Nacional de Docentes de Nível Superior na área de Ginástica, Escola Superior de Educação Física, Universidade Federal de Pelotas, 1980.

MAZO, Janice Zarpellon; LYRA, Vanessa Bellani. Nos rastros da memória de um "Mestre de Ginástica". Motriz, Rio Claro, v.16 n.4 p.967-976, out./dez. 2010.

MÜLLER, Telmo Lauro. Sociedade Ginástica: cem anos de história. São Leopoldo: Rotermund, 1986.

PESAVENTO, Sandra Jatahy. História e história cultural. 2. ed. Belo Horizonte: Autêntica, 2004.

PFANDFINDERGRUPPE. São Sebastião do Caí. Compilação de textos, 1938. Encontrado no Acervo Benno Mentz, Instituto Delfos/PUCRS.

QUITZAU, Evelise Amgarten. Associativismo ginástico e escotismo no Rio Grande do Sul (1913-1934). Revista História da Educação (Online), v. 23, 2019.

QUITZAU, Evelise Amgarten. Associativismo ginástico e imigração alemã no sul e sudeste do Brasil (18581938). 242f. 2016. Tese (Doutorado em Educação). Universidade Estadual de Campinas. Campinas, 2016.

RAMBO, Arthur Blásio. A Escola Comunitára teuto-brasileira católica: a Associação dos Professores e Escola Normal. São Leopoldo: UNISINOS, 1996.

RAMBO, Arthur Blásio. A Escola Comunitária Teuto-Brasileira Católica. São Leopoldo: Ed. Unisinos, 1994. 
RAMOS, Eloísa. O teatro da sociabilidade: os clubes sociais como espaço de representação das elites urbanas alemãs e teuto-brasileiras - São Leopoldo 1858-1930. Tese (Doutorado em História). Universidade Federal do Rio Grande do Sul (UFRGS). Porto Alegre, 2000.

ROCHA, Carolina; WASKOW, Denise. Sogipa: 150 anos de vida e história. Porto Alegre: Palavra Bordada, 2017.

ROCHE, Jean. A Colonização Alemã e o Rio Grande do Sul. Porto Alegre: Globo, 1969.

SCHRÖTER, Arthur; BLACK, Georg. Turn-Bericht. Jahres-Bericht 1910. Relatório anual, Turnerbund, Porto Alegre, 30 jan. 1911. Encontrado no Acervo Benno Mentz, Instituto Delfos/PUCRS.

SEYFERTH, Giralda. Socialização e etnicidade: a questão escolar teuto-brasileira (1850-1937). Mana, v. 23, n. 3, 2017, p. 579-607.

SEYFERTH, Giralda. Etnicidade e cultura: a constituição da identidade teuto-brasileira. In: ZARUR, G. C. L (Org.). Etnia y Nación en América Latina. INTERAMER, n.45, v.II, 1992.

SILVA, Haike Roselane da. A identidade teuto-brasileira pensada pelo intelectual Aloys Friederichs. Anos 90, Porto Alegre, v. 12, n. 21/22, p. 295-330, jan./dez. 2005a.

SILVA, Haike Roselane da. A trajetória de uma liderança étnica: J. Aloys Friederichs (1868-1950). 2005. 341 f. Tese (Doutorado em História) - Universidade Federal do Rio Grande do Sul, Porto Alegre, 2005b.

SILVA, Haike Roselane da. SOGIPA: Uma trajetória de 130 anos (publicação comemorativa). Porto Alegre: Gráfica Editora Palloti, Editores Associados Ltda, 1997.

TURNER-BUND Porto Alegre (1892-1917). Livro comemorativo 25 anos, Turnerbund, Porto Alegre, 1917. Encontrado no Acervo Benno Mentz, Instituto Delfos/PUCRS.

TURNWESEN. Kolonie, Santa Cruz do Sul, 11 mar. 1914 Encontrado no Centro de Documentação da UNISC.

UNSER VORTURNERSCHAFT Jahres-Bericht des "Turner-Bundes" zu Porto Alegre. Relatório anual, Turnerbund, Porto Alegre, 30 jan. 1908. Encontrado no Acervo Benno Mentz, Instituto Delfos/PUCRS.

WIESER, Lothar; LEITE, Luciana. Educação Física - Pioneiros do RS: Georg Black. In: MAZO, Janice Zarpellon; REPPOLD FILHO, Alberto. (Org.). Atlas do Esporte no Rio Grande do Sul: atlas do esporte, da educação física e atividades de saúde e lazer no Rio Grande do Sul. Porto Alegre: CREF2/RS, 2005.

WIESER, L. Deutsches Turnen in Brasilien: deustche Auswanderung und die Entwicklung des deutschbrasilianischen Turnwesens bis zum jahre 1917. London: Arena Publications Limited, 1990. 
TELLES, Leandro. Do Deutscher Hilfsverein ao Colégio Farroupilha (1858/1974). Obra comemorativa pelo sesquicentenário da imigração alemã. Porto Alegre: Associação Beneficiente e Educacional de 1858, 1974.

TESCHE, Leomar. Turnen: um símbolo identitário no Brasil. In: TESCHE, Leomar (Org). Turnen: transformações de uma cultura corporal européia na América. Ijuí: Editora Unijuí, 2011. p. 81- 108.

TURNVEREIN SANTA CRUZ. Festschrift von der VII Turnfest der Turnerschaft von Rio Grande do Sul. Livro Comemorativo. Porto Alegre: Martin Fischer, 1929. Encontrado no Centro de Documentação da UNISC.

TURNVEREIN SÃO JOÃO do Montenegro. Festschrift von der VII Turnfest der Turnerschaft von Rio Grande do Sul. Livro Comemorativo. Porto Alegre: Martin Fischer, 1929. Encontrado no Centro de Documentação da UNISC.

TURNVEREIN CAHY Jamboree. Folheto de programação do evento, São Sebastião do Caí, set. 1927 Encontrado no Acervo Benno Mentz, Instituto Delfos/PUCRS.

UNSER TURNBETRIEB. Jahres-Bericht 1913. Relatório anual, Turnerbund, Porto Alegre, 21 jan. 1914. Encontrado no Acervo Benno Mentz, Instituto Delfos/PUCRS.

RECEBIDO EM: $31 / 03 / 2020$

APROVADO EM: 23/04/2020 